\title{
Kestabilan emulsi dan oksidasi low fat mayonnaise menggunakan kefir se- bagai alternatif emulsifier
}

\section{Determining emulsion and oxidation stability of low fat mayonnaise using kefir as alternative emulsifiers}

\author{
Herly Evanuarini ${ }^{*}$, Nurliyani ${ }^{2)}$, Indratiningsih ${ }^{2)}$, dan Pudji Hastuti ${ }^{3)}$ \\ 1) Bagian Teknologi Hasil Ternak, Fakultas Peternakan, Universitas Brawijaya \\ 2) Jurusan Teknologi Hasil Ternak, Fakultas Peternakan, Universitas Gadjah Mada \\ 3) Teknologi Hasil Pertanian, Universitas Gadjah Mada
}

Submitted: 01 Maret 2019, Accepted: 28 April 2019

\begin{abstract}
ABSTRAK: Mayonnaise adalah saus popular berbentuk semi solid minyak dalam air yang tersusun atas minyak, pengasam dan telur yang dipasteurisasi sebagai emulsifier. Permintaan konsumen saat ini menghendaki makanan yang alami menyehatkan dan rendah kalori sehingga, dilakukan inovasi dan pembuatan produk low fat. Emulsifier yang sering digunakan adalah lesitin kuning telur, kasein, dan whey. Kefir dapat digunakan sebagai pengganti emulsifier dalam pembuatan low fat mayonnaise. Penggunaan kuning telur dikurangi dan kefir digunakan sebagai emulsifier pengganti kuning telur. Tujuan dari penelitian ini adalah untuk mengetahui kestabilan emulsi, antioksidan, dan kestabilan oksidasi dari mayonnaise yang terbuat dari rice bran oil dan kefir selama penyimpanan. Metode penelitian menggunakan metode percobaan laboratorium. Hasil penelitian menunjukkan penggunaan kefir dalam low fat mayonnaise dapat meningkatkan kestabilan emolsi dan kestabilan oksidasi.
\end{abstract}

Kata kunci : Low fat mayonnaise; kefir; kestabilan emulsi; antioksidan; kestabilan oksidasi.

ABSTRACT: Mayonnaise is popular sauce. It's kind of semi solid oil in water (o/w) emulsion which containing oil, acidifier and pasteurized egg yolk as an emulsifier. The consumers have demanded that for natural, healthy, and low calorie food especially for development and manufacture of low fat mayonnaise. The common emulsifiers are egg yolk, casein, and whey. Kefir can replace egg yolk to develop low fat mayonnaise. The use of egg yolk be reduced and kefir was used to develop a low fat mayonnaise as emulsifier replacer to egg yolk. The purpose of this research attempts to observe the emulsion stability, antioxidant, and oxidation stability of low fat mayonnaise prepared using rice bran oil and kefir during storage. The research methods using experimental design. The result shows the addition of kefir can create low fat mayonnaise by increasing emulsion stability.

Keywords : Low fat mayonnaise; kefir; emulsion stability; antioxidant; oxidation stability.

*Corresponding Author: herlyfptub@ub.ac.id

DOI: 10.21776/ub.jiip.2019.029.01.10 


\section{PENDAHULUAN}

Mayonnaise merupakan produk pangan berbentuk emulsi yang saat ini sangat dikenal sebagai saus yang digunakan dalam salad, sandwich maupun pangan lainnya. Saat ini dengan semakin tingginya kesadaran masyarakat tentang pentingnya kesehatan, maka produsen harus memahami keinginan konsumen yaitu membuat pangan fungsional, produk low fat, maupun low calorie. Low fat mayonnaise merupakan suatu produk yang dikehendaki oleh konsumen. Tiga fase penting dalam terbentuknya emulsi mayonnaise adalah fase minyak, fase air dan emulsifier. Emulsifier yang selama ini digunakan adalah kuning telur, salah satu upaya untuk menurunkan kandungan lemak pada mayonnaise adalah menurunkan penggunaan kuning telur dengan menggunakan emulsifier lainnya. Penggunaan emulsifier selain kuning telur memiliki keuntungan antara lain menurunkan secara umum kandungan lemak dan meningkatkan stabilitas (Ricardo, et al., 2003). Bahan yang dapat digunakan sebagai emulsifier adalah protein whey, casein, protein dari nabati seperti protein bunga matahari (Raymundoa, 2002). Protein susu yaitu casein banyak digunakan sebagai emulsifier dalam bahan pangan. Sejauh ini penggunaan susu fermentasi (kefir) sebagai alternatif pengganti emulsifier belum pernah dilakukan. Penggunaan kefir ini ini diharapkan mampu membentuk kestabilan emulsi serta mampu memperbaiki kestabilan oksidasi pada low fat mayonnaise

Kestabilan oksidasi merupakan ketahanan oksidasi sejak proses produksi hingga penyimpanan. Efek kondisi pada suhu dan lama penyimpanan terhadap oksidasi diekspresikan sebagai peroxide value, anisidine value, dan totox value. Berbagai faktor yang mempengaruhi stabilitas oksidasi antara lain: struktur kimia lemak, konsentrasi oksigen, antioksidan, dan ketersediaan pro oksidan (Mc. Clements and Dekker, 2000). Oksidasi lemak adalah salah satu penyebab serius penurunan kualitas berbagai bahan pangan karena menyebabkan off flavors dan off odors (Mc. Clements, 1999). Peroxide value digunakan untuk memonitor pembentukan peroksida pada tahap awal oksidasi. Pembentukan produk oksidasi sekunder pada penyimpanan dijelaskan dengan anisidine value. Totox value mengukur laju penurunan kualitas minyak/lemak, dan memberikan informasi laju pembentukan produk oksidasi primer dan sekunder (Shahidi and Wanasundara, 2002). Peneltian bertujuan untuk mengetahui aktivitas antioksidan, stabilitas emulsi, kestabilan oksidasi, serta low fat mayonnaise selama penyimpanan pada suhu ruang dan suhu refrigerator $\left(5^{\circ} \mathrm{C}\right)$.

\section{MATERI DAN METODE}

Materi yang digunakan dalam penelitian ini adalah soya oil untuk pembuatan mayonnaise kontrol, rice bran oil, tepung porang dari Pare Kediri, susu segar. Kefir grains diperoleh dari Laboratorium Mikrobiologi Teknologi Hasil Ternak Fakultas Peternakan UB, kuning telur, vinegar, garam, gula, lada, mustard, distilled water dan bahan bahan untuk analisa kimia.

Komposisi mayonnaise kontrol dan low fat mayonnaise yang diformulasi dari rice bran oil, tepung porang dan kefir dalam penelitian dapat dilihat pada Tabel 1 .

\section{Persiapan pembuatan kefir}

Pembuatan kefir dilakukan sebagai berikut: Susu segar dipasteurisasi $63^{\circ} \mathrm{C}$ selama 15 menit, selanjutnya didinginkan hingga $25^{\circ} \mathrm{C}$, dan diinokulasi kefir grains sebesar $4 \%$. Fermentasi dilakukan pada inkubator pada suhu $38^{\circ} \mathrm{C}$ selama 18 jam. Pemisahan koagulum dilakukan dengan penyaringan.

\section{Persiapan sampel mayonnaise}

Bahan yang digunakan dalam pembuatan mayonnaise disajikan pada Tabel 1 dengan menggunakan kefir sebagai emulsi- 
fier dan substitusi kuning telur. Prosedur diawali dengan pencampuran bahan garam, gula, mustard, lada putih, sebagian kuning telur dengan menggunakan mixer dengan kecepatan 1500 rpm selama 1 menit selanjutnya dimasukkan sepertiga dari jumlah minyak dan bergantian dengan vinegar dan kefir, selanjutnya dimasukkan tepung porang yang sudah dilarutkan pada air hangat dan bergantian kembali dilakukan penambahan minyak, vinegar, kefir bergantian hingga terbentuk emulsi.

Tabel 1. Formulasi mayonnaise kontrol dan low fat mayonnaise yang diformulasi dari RBO, tepung porang dan kefir selama penyimpanan

\begin{tabular}{lcccc}
\hline \multirow{2}{*}{ Komponen } & \multicolumn{4}{c}{ Perlakuan } \\
\cline { 2 - 5 } & M0 & M1 & M2 & M3 \\
\hline Soya oil (v/v) & 70 & - & - & - \\
RBO (v/v) & - & 30 & 40 & 50 \\
Kuning telur & 15 & 12 & 12 & 10,5 \\
Kefir & - & 3 & 3 & 4,5 \\
Vinegar & 5 & 5 & 5 & 5 \\
Garam & 1,5 & 1,5 & 1,5 & 1,5 \\
Gula & 2 & 2 & 2 & 2 \\
Mustard & 1,5 & 1,5 & 1,5 & 1,5 \\
Lada putih & 0,5 & 0,5 & 0,5 & 0,5 \\
Tepung porang & - & 0,3 & 0,3 & 0,2 \\
Air & 4,5 & 44,2 & 34,2 & 24,3 \\
\hline
\end{tabular}

Ket : M0 = kontrol full fat, $\mathrm{M} 1=\mathrm{RBO} 30 \%$, porang $0,3 \%$, kefir $20 \%$; $\mathrm{M} 2=\mathrm{RBO} 40 \%$, porang $0,3 \%$, kefir 20\%; M3 = RBO 50\%, porang 0,2\%, kefir 30\%

Mayonnaise yang dihasilkan disimpan pada suhu ruang dan refrigerator $5^{\circ} \mathrm{C}$, sesuai perlakuan yaitu selama $0,10,20,30$ hari. Selanjutnya dilakukan pengukuran kestabilan emulsi terhadap pemisahan fase minyak dan fase air menggunakan metode stability rating menurut Mun et al. (2009), pengukuran aktivitas antioksidan dengan 1,1-Dihenyl-2-Picrylhydrazyl (DPPH) menurut (Nagwa et al., 2012), angka peroksida (AOAC, 2000), anisidine value menggunakan spektrofotometri dan totox value menurut American Oil Chemists Society (1998).

Metode yang digunakan dalam penelitian adalah metode percobaan dengan menggunakan 4 perlakuan dengan 3 ulangan. Data dianalisis dengan menggunakan analisis variansi (ANOVA) pola searah. Aktivitas antioksidan, kestabilan emulsi dan totox value mayonnaise disajikan dengan analisis regresi untuk mengetahui laju aktivitas antioksidan, laju kestabilan emulsi dan laju kerusakan oksidasinya.

\section{HASIL DAN PEMBAHASAN}

Penyimpanan mayonnaise akan menyebabkan penurunan kualitas mayonnaise meliputi destabilisasi fisik, oksidasi, mikrobiologis dan interaksinya. Penyimpanan pada suhu tinggi akan memicu penurunan kestabilan emulsi dan kestabilan oksidasi mayonnaise. Stabilitas mayonnaise sangat dipengaruhi oleh suhu dan lama penyimpanan serta bahan-bahan penyusun mayonnaise. Kuning telur mengandung beta karoten sebesar 3388,31 $\mu \mathrm{g} / 100 \mathrm{~g}$. Hasil analisis komposisi asam lemak dan komponen antioksidan bahan penyusun mayonnaise, rice bran oil dan kefir disajikan pada Tabel 2. 
Tabel 2. Komposisi asam lemak dan komponen antioksidan rice bran oil dan kefir

\begin{tabular}{lcc}
\hline \multirow{2}{*}{ Kandungan Senyawa } & \multicolumn{2}{c}{ Komposisi } \\
\cline { 2 - 3 } & Rice Bran Oil $(\%)$ & Kefir $(\%)$ \\
\hline Asam Laurat & 1,05 & 5,83 \\
Asam Miristat & 2,15 & 5,51 \\
Asam Palmitoleat & 13,5 & 12,16 \\
Asam Palmitat & 2,6 & 5,95 \\
Asam Linolenat & 6,9 & 25,63 \\
Asam Linoleat & 29,78 & 18,37 \\
Asam Oleat & 19,60 & 16,64 \\
Tocotrienol & 0,29 & - \\
Ergosterol & 0,80 & - \\
Campesterol & 0,85 & - \\
Oryzanol & 3,91 & - \\
-Carotene & 0,50 & 4,83 \\
Tocopherol & 0,29 & 5,06 \\
\hline
\end{tabular}

\section{Aktivitas antioksidan}

Laju aktivitas antioksidan mayonnaise dengan variasi minyak, tepung porang, dan kefir pada penyimpanan suhu ruang dan refrigerator selama $0,10,20$, dan 30 hari tertera pada regresi Gambar 1 dan Gambar 2.

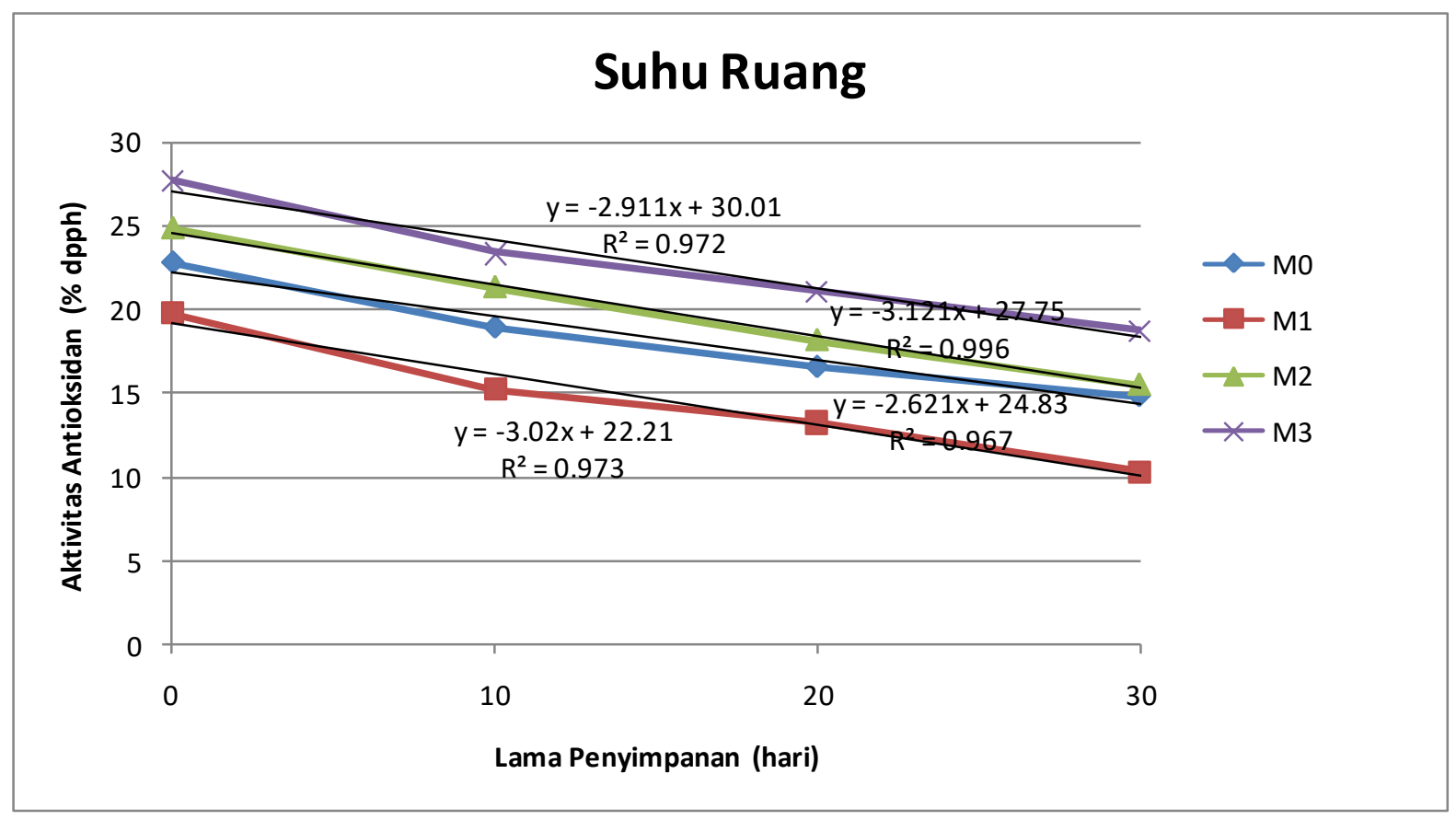

Gambar 1. Regresi aktivitas antioksidan mayonnaise dari variasi minyak, tepung porang dan kefir pada penyimpanan suhu ruang selama $0,10,20$, dan 30 hari. ( $y=$ aktivitas antioksidan, $\mathrm{x}=$ lama penyimpanan). 


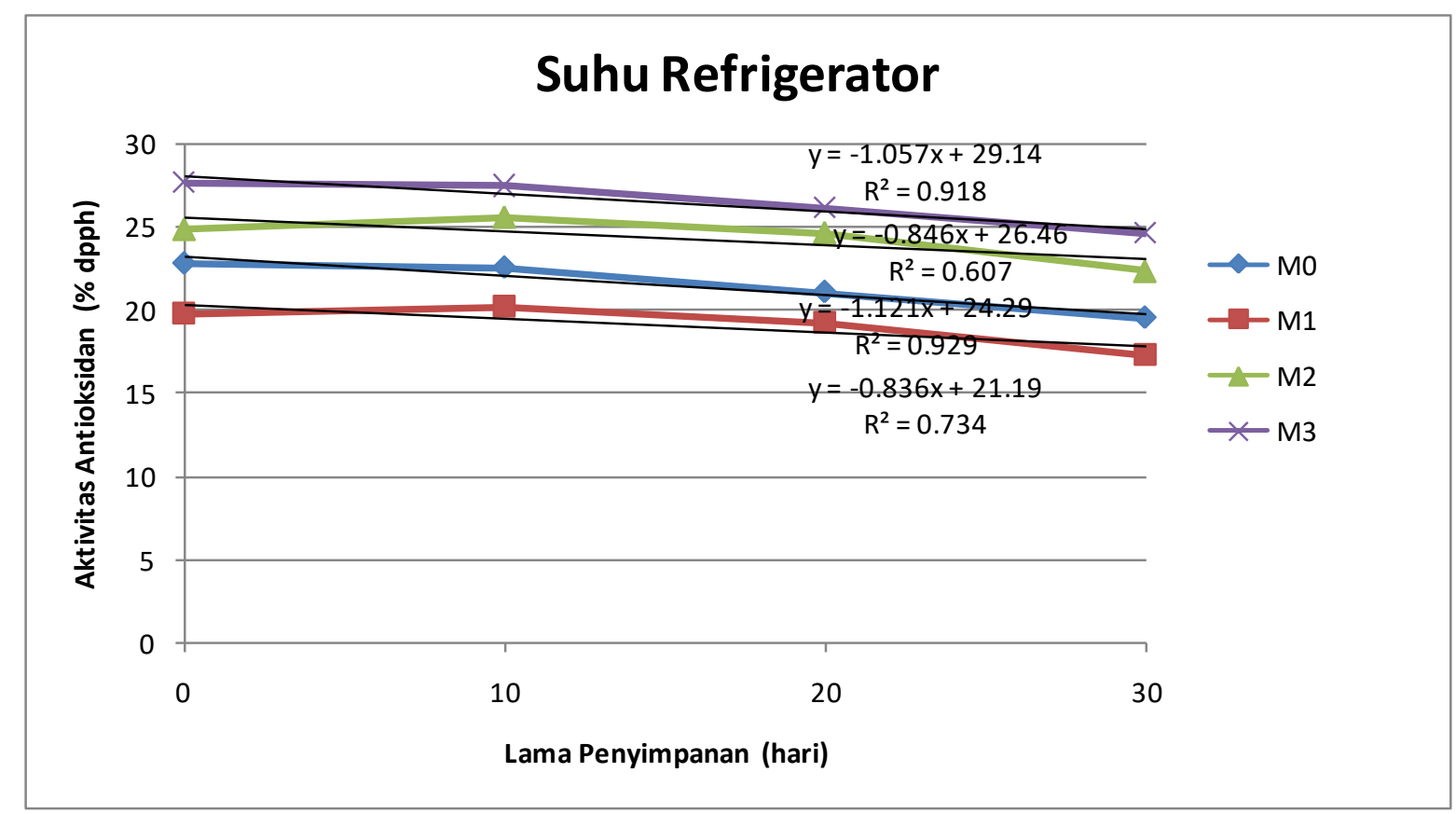

Gambar 1. Regresi aktivitas antioksidan mayonnaise dari variasi minyak, tepung porang dan kefir pada penyimpanan suhu refrigerator selama 10, 20, dan 30 hari. (y= aktivitas antioksidan, $\mathrm{x}=$ lama penyimpanan).

(Ket: $\mathrm{M} 0=$ kontrol; $\mathrm{M} 1=\mathrm{RBO} 30 \%$, porang 0,3\%, kefir 20\%; M2 $=$ RBO 40\%, porang 0,3\%, kefir 20\%; M3 = RBO $50 \%$, porang 0,2\%, kefir 30\%)

Perlakuan penggunaan minyak, tepung porang, dan kefir yang berbeda pada suhu dan lama penyimpanan memiliki pengaruh yang berbeda terhadap aktivitas antioksidan mayonnaise selama penyimpanan. Perbedaan nilai aktivitas antioksidan ini dipengaruhi oleh konsentrasi minyak dan kefir yang digunakan. Semakin tinggi minyak dan kefir yang digunakan, meningkatkan nilai aktivitas antioksidan mayonnaise. Hal ini disebabkan RBO memiliki kandungan tocopherol, tocotrienol dan oryzanol yang mampu berperan sebagai antioksidan. Aktivitas antioksidan tocopherol berhubungan dengan kemampuannya mendonasikan hidrogen ke radikal peroxyl lemak. Penelitian Gavahian et al. (2011) menyatakan penambahan minyak atsiri dalam pembuatan mayonnaise dengan konsentrasi yang berbeda dan penyimpanan pada suhu $37^{\circ} \mathrm{C}$ dengan lama simpan 11 minggu memiliki aktivitas antioksidan berbeda. Aktivitas antioksidan yang stabil selama penyimpanan diperoleh pada kon- sentrasi minyak tertinggi. Konsentrasi minyak atsiri mengandung komponen antioksidan seperti thymol, gamma-terpinene dan p-cymene tinggi. Komponen ini mampu mencegah terjadinya peroksidasi lipid dengan cara mencegah proses awal terbentuknya asam lemak bebas dengan menghambat reaksi propagasi pada mayonnaise.

Kandungan beta karoten dan tocopherol yang ada pada kefir juga diduga mampu meningkatkan aktivitas antioksidan mayonnaise. Ditambahkan oleh Liu, Xu and Guo, (2012), bahwa susu fermentasi memiliki aktivitas antioksidan yang tinggi dibanding susu segar dan memiliki mekanisme untuk menghambat peroksidase asam linoleat serta kekuatan mereduksi yang baik terutama aktivitas mereduksi glutathion peroksidasi dalam susu. Penelitian Moslehishad et al. (2013) menemukan bahwa susu yang difermentasi oleh bakteri Lactobacillus rhonnosus merupakan strain proteolitik yang dapat 
menyebabkan terbebasnya ACE-inhibitor dan peptida antioksidan dari protein susu. Analisis regresi aktivitas antioksidan mayonnaise selama penyimpanan menghasilkan slope seperti tertera pada Tabel 3.

Tabel 3. Slope aktivitas antioksidan mayonnaise yang disimpan pada suhu ruang dan suhu refrigerator

\begin{tabular}{lll}
\hline Perlakuan & Suhu ruang & Suhu refrigerator \\
\hline M0 & $-2,62$ & $-1,12$ \\
M1 & $-3,02$ & $-0,84$ \\
M2 & $-3,12$ & $-0,85$ \\
M3 & $-2,91$ & $-1,06$ \\
\hline
\end{tabular}

Nilai slope yang negatif mencerminkan arah regresi linier yang negative. Hal ini menunjukkan bahwa aktivitas antioksidan akan semakin turun dengan semakin lama waktu penyimpanan. Pendugaan penurunan aktivitas antioksidan setiap 10 hari akan turun sebesar 2,62 untuk M0; 3,02 untuk M1; 3,12 untuk M2; dan 2,91 untuk M3 pada suhu ruang. Pada suhu refrigerator, laju penurunan aktifitas antioksidan lebih lambat yaitu 1,12 untuk M0; 0,84 untuk M1; 0,85 untuk M2; dan 1,06 untuk M3.

Penurunan aktivitas antioksidan yang lebih cepat pada suhu ruang dibandingkan dengan suhu refrigerator diduga karena suhu mempengaruhi aktivitas komponen mayonnaise. Suhu refrigerator mampu menghambat oksidasi dibanding suhu ruang karena aktivitas lipolitik terhambat pada suhu refrigerator.

\section{Kestabilan emulsi}

Regresi kestabilan emulsi mayonnaise dengan variasi minyak, tepung porang, dan kefir pada penyimpanan suhu ruang dan refrigerator selama $0,10,20$, dan 30 hari tertera pada Gambar 3 dan Gambar 4.

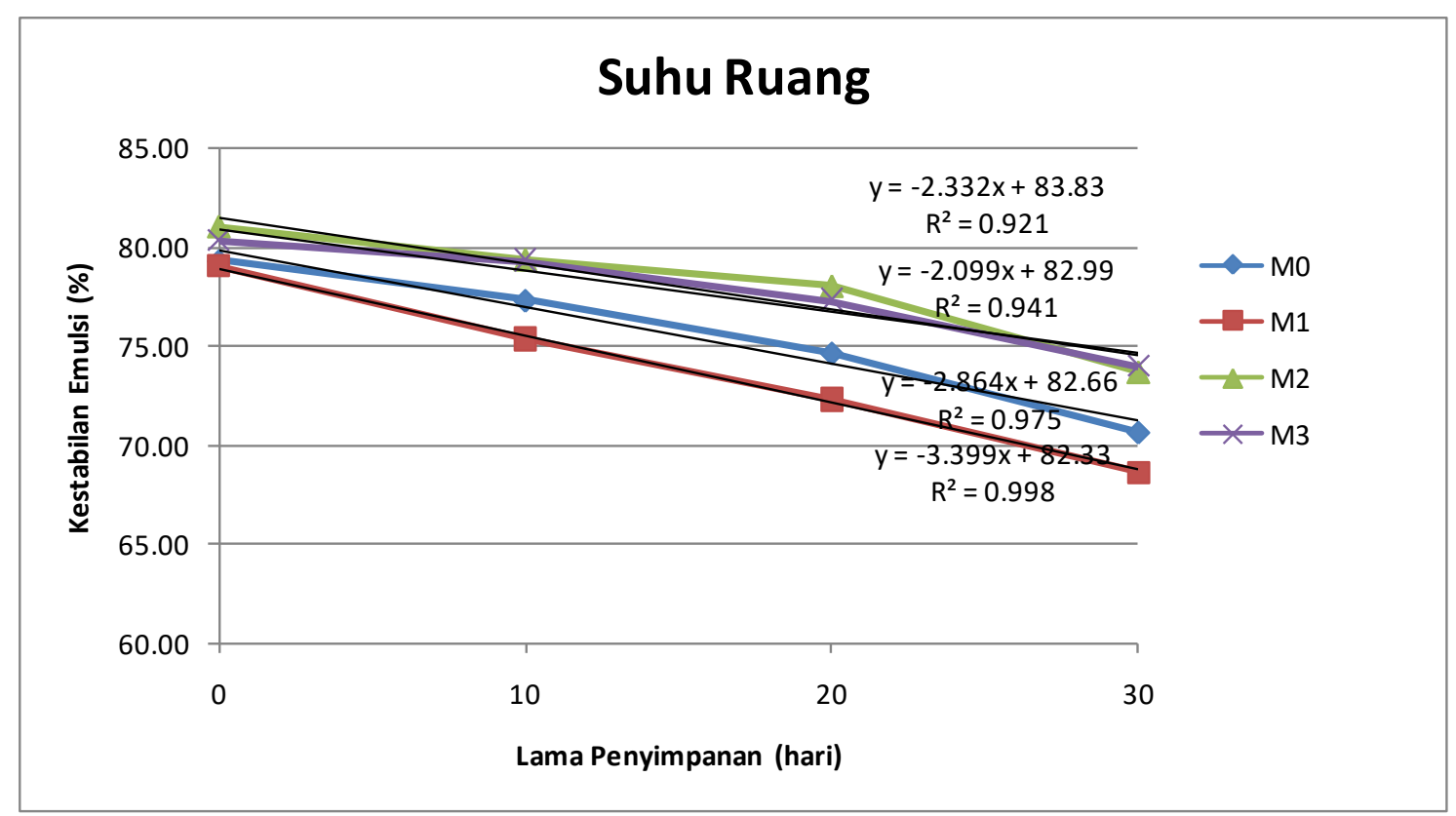

Gambar 3. Regresi kestabilan emulsi mayonnaise dari variasi minyak, tepung porang dan kefir pada penyimpanan suhu ruang selama $0,10,20$, dan 30 hari. ( $\mathrm{y}=$ kestabilan emulsi, $\mathrm{x}=$ lama penyimpanan). 
Penambahan tepung porang mampu menstabilkan emulsi dengan meningkatkan viskositas pada fase kontinyu dan menurunkan pergerakan droplet minyak. Karakteristik emulsi yang dihasilkan tergantung pada konsentrasi minyak dan komposisi fase kontinyu. Persentase hidrokoloid juga mempengaruhi kestabilan emulsi mayonnaise. Tabilo Munizaga dan
Barbosa (2005) menyatakan polisakarida sering ditambahkan pada fase air pada produk low fat emulsi untuk meningkatkan stabilitas. Analisis regresi kestabilan emulsi mayonnaise selama penyimpanan menghasilkan slope seperti tertera pada Tabel 4.

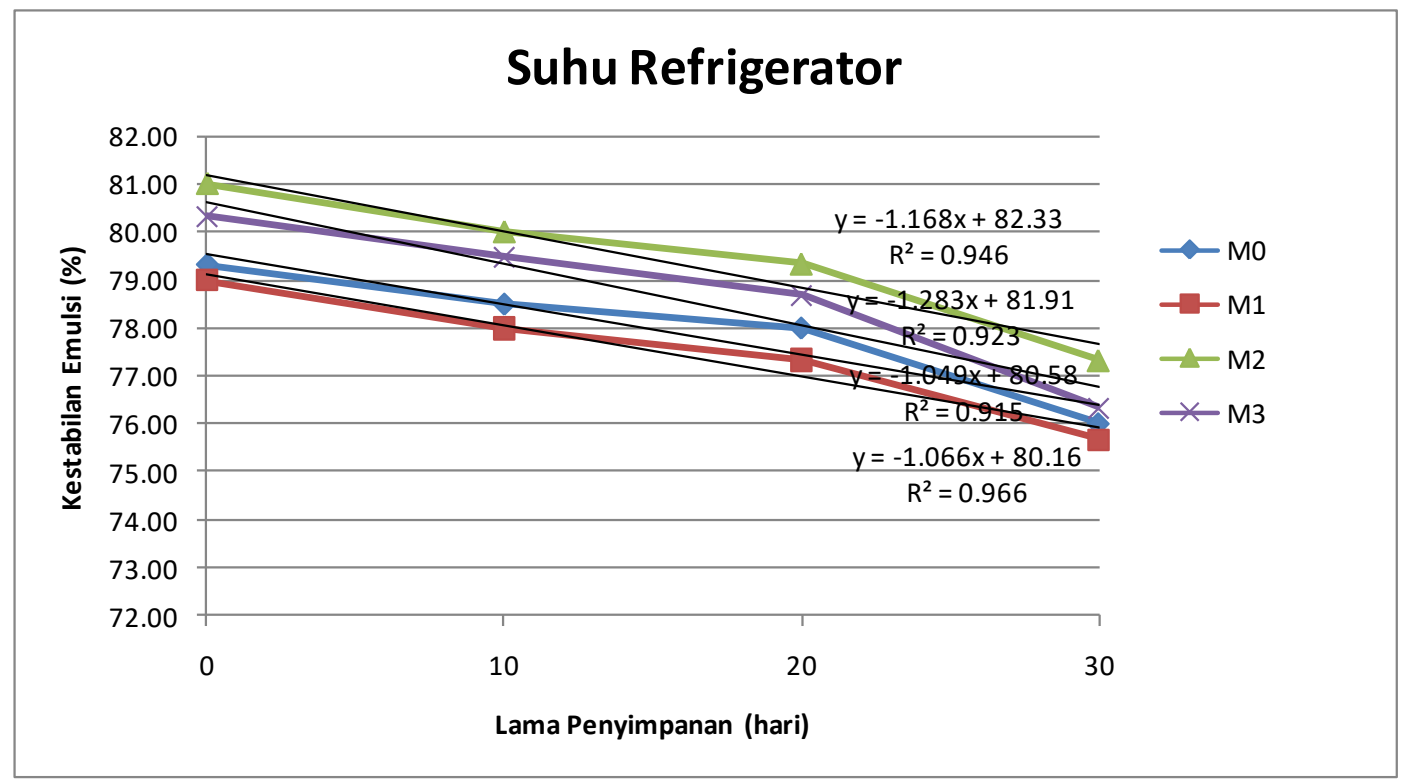

Gambar 4. Regresi kestabilan emulsi mayonnaise dari variasi minyak, tepung porang dan kefir pada penyimpanan suhu refrigerator selama 10, 20, dan 30 hari. $(y=$ kestabilan emulsi, $\mathrm{x}=$ lama penyimpanan).

(Ket.: $\mathrm{M} 0=$ kontrol; $\mathrm{M} 1=\mathrm{RBO} 30 \%$, porang 0,3\%, kefir $20 \%$; $\mathrm{M} 2=\mathrm{RBO} 40 \%$, porang $0,3 \%$, kefir $20 \%$; M3 $=$ RBO $50 \%$, porang $0,2 \%$, kefir $30 \%$ ).

Tabel 4. Slope kestabilan emulsi mayonnaise yang disimpan pada suhu ruang dan suhu refrigerator

\begin{tabular}{lll}
\hline Perlakuan & Suhu ruang & Suhu refrigerator \\
\hline M0 & $-2,86$ & $-1,05$ \\
M1 & $-3,39$ & $-1,07$ \\
M2 & $-2,33$ & $-1,17$ \\
M3 & $-2,09$ & $-1,28$ \\
\hline
\end{tabular}

Nilai slope kestabilan emulsi yang negatif mencerminkan arah regresi linier yang negative. Hal ini menunjukkan bahwa kestabilan emulsi akan semakin turun dengan semakin lama waktu penyimpanan. Pendugaan penurunan kestabilan emulsi setiap 10 hari akan turun sebesar 2,86 untuk M0; 3,39 untuk M1; 2,33 untuk M2; dan 2,09 untuk M3 pada suhu ruang. Pada suhu refrigerator, laju penurunan kestabilan emulsi lebih lambat yaitu 1,05 untuk M0; 1,07 untuk M1; 1,17 untuk M2; dan 1,28 untuk M3.

Penggunaan minyak yang lebih tinggi akan menghasilkan kestabilan emulsi yang lebih tinggi. Mayonnaise yang tinggi min- 
yak secara umum stabil dari pemisahan fase, ketika minyak dikurangi, emulsinya menjadi tidak stabil, sehingga dibutuhkan hidrokoloid untuk mencegah terpisahnya fase terdispersi dan pendispersi selama penyimpanan. Penggunaan kefir dan kuning telur sebagai emulsifier memiliki permukaan aktif yang akan teradsorpsi di permukaan membentuk droplet baru dan sebagai proteksi membran, sehingga mencegah droplet menyatu. Penyimpanan pada suhu ruang akan menurunkan kestabilan emulsi lebih cepat dari penyimpanan pada suhu refrigerator.

\section{Totox value}

Nilai total oksidasi mengestimasi laju kerusakan oksidasi produk lemak atau minyak. Totox value dihitung dari 2 kali angka peroksida ditambah anisidine value. Indikator ini mengukur laju penurunan kualitas produk dan memberikan informasi laju pembentukan produk oksidasi primer dan sekunder.

\section{Angka peroksida}

Perlakuan penggunaan minyak, tepung porang dan variasi kefir pada suhu dan lama penyimpanan yang berbeda, menghasilkan rata-rata angka peroksida yang berbeda pada mayonnaise selama penyimpanan. Perbedaan angka peroksida dipengaruhi oleh jumlah minyak dan kefir yang digunakan serta seiring bertambahnya lama simpan. Semakin tinggi minyak dan kefir yang digunakan akan menghasilkan angka peroksida mayonnaise yang rendah. Nilai peroksida mayonnaise yang rendah mengindikasikan bahwa potensi mayonnaise untuk mengalami kerusakan karena oksidasi juga rendah. Penelitian Hashemi et al. (2012), penambahan minyak dalam pembuatan saus dressing dengan konsentrasi yang berbeda pada suhu $37^{\circ} \mathrm{C}$ selama 11 minggu menunjukkan perbedaan yang nyata.

Semakin tinggi konsentrasi RBO yang digunakan pada pembuatan low fat mayon- naise, menghasilkan angka peroksida semakin rendah. Hal ini dikarenakan konsentrasi RBO yang tinggi juga mengandung antioksidan yang tinggi seperti tocopherol, tocotrienol, gamma oryzanol dan beta karoten. Komponen ini mampu mencegah terjadinya peroksidasi lemak selama penyimpanan. Stabilitas oksidasi mayonnaise tergantung pada tipe minyak yang digunakan. Penggunaan kefir pada pembuatan mayonnaise diduga juga memiliki kemampuan mereduksi aktivitas oksidasi. Oksidasi lemak yang dihambat oleh kefir ini menyebabkan nilai peroksida mayonnaise menurun. Liu, $\mathrm{Xu}$ and Guo. (2007) menyatakan bahwa kefir memiliki aktivitas antioksidan yang tinggi dibanding susu segar.

Suhu penyimpanan dan lama simpan mayonnaise juga memiliki pengaruh terhadap kualitas mayonnaise. Rata-rata angka peroksida yang dihasilkan menunjukkan bahwa penyimpanan mayonnaise pada suhu ruang menghasilkan angka peroksida yang tinggi dan secara bertahap meningkat dengan rentang cukup besar. Angka peroksida mayonnaise yang disimpan pada su$\mathrm{hu}$ refrigerator mengalami peningkatan, namun tidak terlalu tinggi jika dibandingkan dengan suhu ruang. Suhu refrigerator mampu menghambat oksidasi lemak dibanding suhu ruang karena aktivitas lipolitik terhambat pada suhu refrigerator, oleh sebab itu peningkatan nilai peroksida pada suhu refrigerator lebih lambat dibandingkan suhu ruang. Hal ini menunjukkan suhu penyimpanan mempengaruhi proses oksidasi. Sampel kontrol mempunyai angka peroksida tertinggi pada penyimpanan 30 hari yaitu sebesar $3,64 \mathrm{meq} / \mathrm{kg}$. Nilai peroksida secara signifikan meningkat dengan peningkatan lama penyimpanan.

\section{Anisidine value}

Mayonnaise kontrol memiliki nilai anisidin tertinggi pada penyimpanan 30 hari yaitu sebesar 10,34. Nilai anisidin yang meningkat mengindikasikan bahwa 
minyak mengalami oksidasi lebih intensif. Mc Clements (1999) menyatakan oksidasi lemak adalah salah satu penyebab serius penurunan kualitas pada beberapa pangan karena hal ini memicu off-flavor dan offodors yang tidak diinginkan. Rata-rata anisidine value terendah didapatkan dari mayonnaise sampel yang menggunakan minyak $50 \%$, tepung porang $0,2 \%$ dan kefir 30\%. Data yang diperoleh berhubungan dengan produk oksidasi primer yang ditentukan dengan angka peroksida.

Komponen antioksidan pada minyak rice bran dan kefir pada mayonnaise diduga mampu menghambat autooksidasi lemak pada ikatan ganda dan pembentukan peroksida, hidroperoksida dan produk dekomposisi khususnya 2 alkenals dan 2,4 alkadienals. Hal ini sesuai dengan pendapat Kochhar dan Rossel (1990) yang menyatakan bahwa antioksidan dapat bertindak sebagai penghambat radikal bebas dan menekan pro oksidan. Setelah 10 hari penyimpanan, AV akan mengalami peningkatan. Mayonnaise yang disimpan pada suhu refrigerator, produk oksidasi sekunder akan mengalami kenaikan namun lebih lambat dibanding suhu ruang. Crapiste, Brevedan and Carelli. (1999) menyatakan bahwa AV pada sunflower oil pada tahap awal penyimpanan konstan, tetapi meningkat pada penyimpanan selanjutnya. Emulsifier efektif menghambat oksidasi lemak karena kemampuan membran interfasial sebagai barier fisik yang memisahkan substrat lemak dari pro oksidan pada fase air. Emulsifier seperti protein dapat bertindak sebagai barier kimia terhadap oksidasi lemak dengan menangkal radikal bebas. Totox value mayonnaise dengan variasi minyak, tepung porang, dan kefir pada penyimpanan suhu ruang dan refrigerator selama $0,10,20$, dan 30 hari tertera pada Gambar 5 dan Gambar 6.

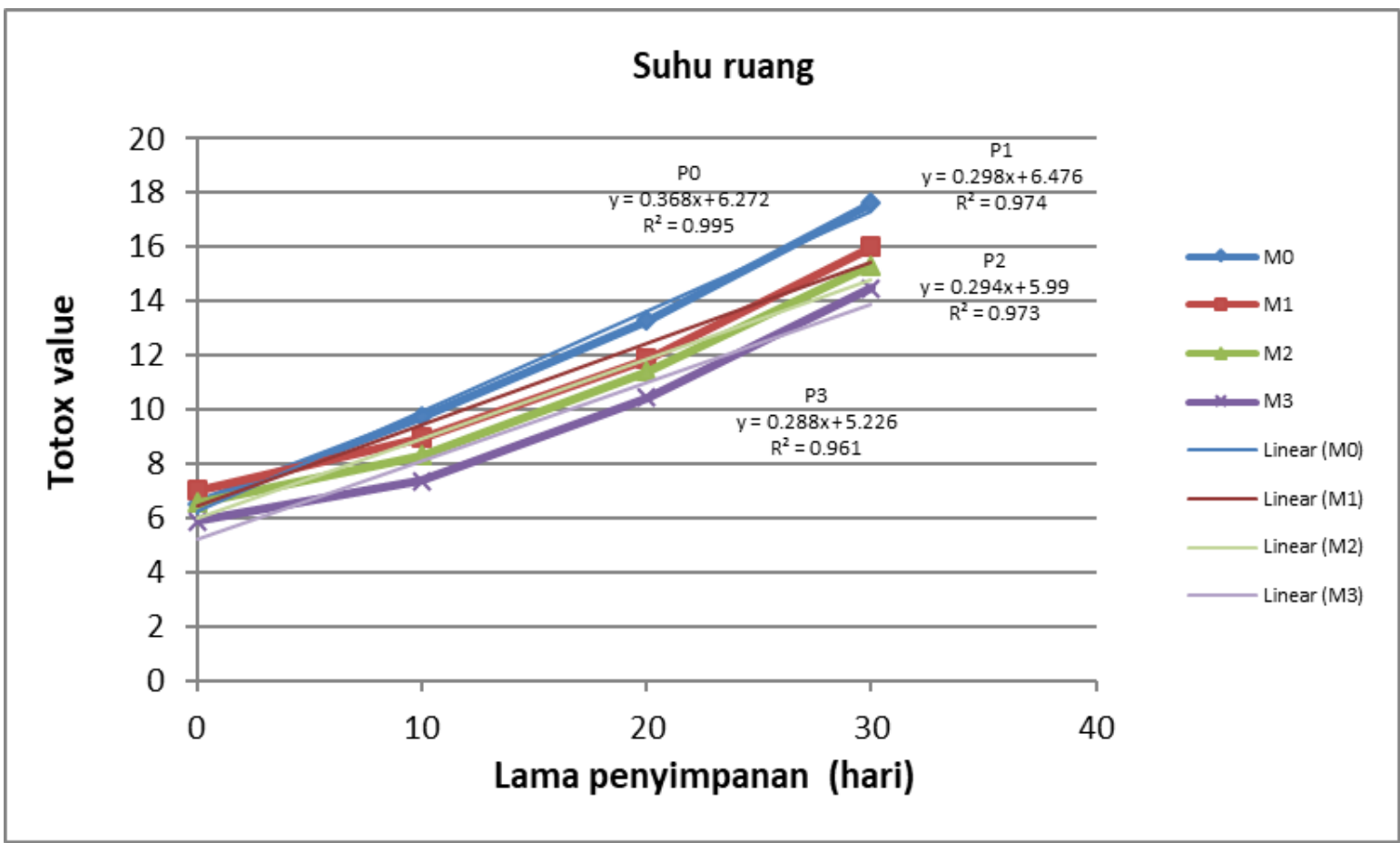

Gambar 5. Regresi totox value mayonnaise dari variasi minyak, tepung porang dan kefir pada penyimpanan suhu ruang selama $0,10,20$, dan 30 hari. ( $y=$ totox value, $x=$ lama penyimpanan). 


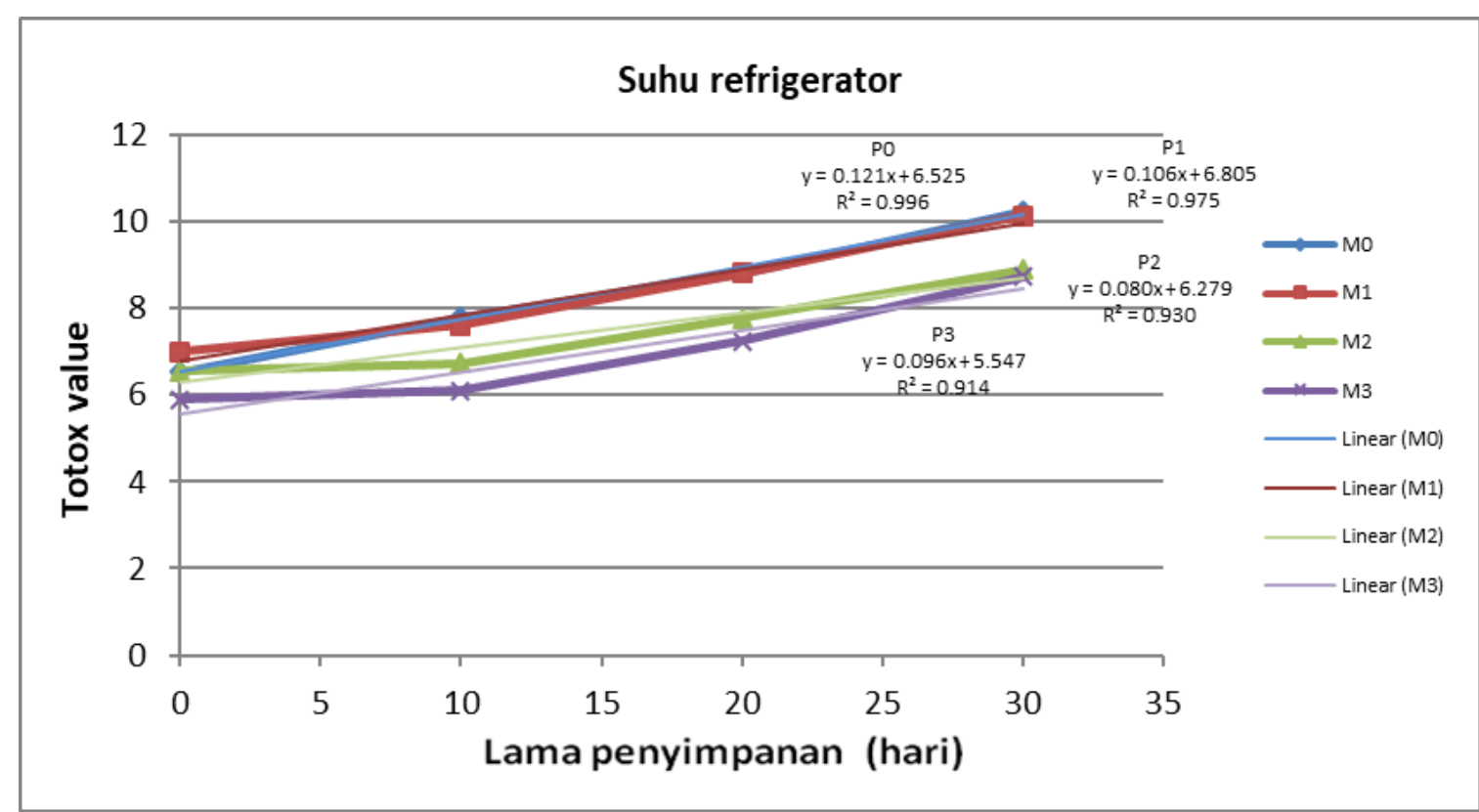

Gambar 6. Regresi totox value mayonnaise dari variasi minyak, tepung porang dan kefir pada penyimpanan suhu refrigerator selama $0,10,20$, dan 30 hari. $(y=$ totox value, $x=$ lama penyimpanan).

(Ket.: $\mathrm{M} 0=$ kontrol; $\mathrm{M} 1=\mathrm{RBO} 30 \%$, porang 0,3\%, kefir $20 \%$; M2 $=$ RBO 40\%, porang $0,3 \%$, kefir $20 \%$; M3 = RBO $50 \%$, porang $0,2 \%$, kefir $30 \%$ ).

Peningkatan totox value secara signifikan terjadi pada penyimpanan dengan suhu ruang. Peningkatan totox value tertinggi didapatkan dari mayonnaise kontrol. Mayonnaise M3 memiliki totox value terendah.
Nilai totox value yang rendah mempunyai arti kualitas mayonnaise yang lebih baik. Analisis regresi nilai totox value mayonnaise selama penyimpanan menghasilkan slope seperti tertera pada Tabel 5.

Tabel 5. Slope totox value mayonnaise yang disimpan pada suhu ruang dan suhu refrigerator

\begin{tabular}{lll}
\hline Perlakuan & Suhu ruang & Suhu refrigerator \\
\hline M0 & 0,37 & 0,12 \\
M1 & 0,30 & 0,11 \\
M2 & 0,29 & 0,08 \\
M3 & 0,28 & 0,09 \\
\hline
\end{tabular}

Nilai slope yang positif mencerminkan arah regresi linier yang positif. Hal ini menunjukkan bahwa totox value akan semakin naik dengan semakin lama waktu penyimpanan. Pendugaan kenaikan totox value setiap 10 hari akan naik sebesar 0,37 untuk M0; 0,30 untuk M1; 0,29 untuk M2; dan 0,28 untuk M3 pada suhu ruang. Pada suhu refrigerator, laju penurunan aktifitas antioksidan lebih lambat yaitu 0,12 untuk M0; 0,11 untuk M1; 0,08 untuk M2; dan 0,09 untuk M3.
Slope yang tinggi pada mayonnaise kontrol mencerminkan laju oksidasi yang lebih tinggi. Persentase penggunaan RBO yang semakin tinggi akan menghasilkan slope yang rendah, hal ini menunjukkan laju oksidasi menurun baik pada suhu ruang maupun suhu refrigerator. Hal ini disebabkan kandungan antioksidan pada $\mathrm{RBO}$, dimana penggunaan minyak yang semakin tinggi, maka kandungan antioksidannya semakin tinggi pula. Slope pada penyimpanan suhu refrigerator lebih 
rendah daripada slope penyimpanan pada suhu ruang. Hal ini berarti laju oksidasi pada suhu refrigerator lebih rendah daripada suhu ruang. Secara umum perlakuan penggunaan $\mathrm{RBO}$ dan kefir pada low fat mayonnaise mencegah pembentukan peroksida sebagai produk oksidasi primer dan mencegah pembentukan produk oksidasi sekunder. Sama dengan perubahan PV dan $\mathrm{AV}$, mayonnaise yang disimpan pada suhu refrigerator, memiliki totox value lebih rendah daripada yang disimpan pada suhu ruang. Komponen antioksidan yang terdapat pada RBO terdegradasi seiring waktu, sehingga kehilangan sifat antioksidan. Hal ini menyebabkan produk oksidasi meningkat seiring dengan peningkatan lama penyimpanan.

\section{KESIMPULAN}

Formulasi low fat mayonnaise dengan penggunaan Rice Bran Oil 50\%, 0,2\% tepung porang, kefir 30\% menghasilkan low fat mayonnaise yang terbaik ditinjau dari aktivitas antioksidan, kestabilan emulsi, kestabilan oksidasi selama penyimpanan, sehingga disarankan untuk membuat low fat mayonnaise sesuai dengan formulasi tersebut.

\section{DAFTAR PUSTAKA}

American Oil Chemist's Society. (1998). Official Methods and Recommended Practices of The AOCS (2nd ed.). New York: S. Champaign.

AOAC. (2000). Official Methods of Analysis of the Association of Official Analytical Chemists (16th ed.). Washington, D.C: Assoc. off. Anal. Chem.

Crapiste, G. H., Brevedan, M. I. V, \& Carelli, A. A. (1999). Oxidation of sunflower oil during storage. Journal of the American Oil Chemists' Society, 76(12), 1437-1443.

https://doi.org/10.1007/s11746-999$\underline{0181-5}$
Gavahian, M., Farahnaky, A., Majzoobi, M., Javidnia, K., Saharkhiz, M. J., \& Mesbahi, G. (2011). Ohmic-assisted hydrodistillation of essential oils from Zataria multiflora Boiss (Shirazi thyme). International Journal of Food Science \& Technology, 46(12), 26192627. https://doi.org/10.1111/j.13652621.2011.02792.x

Hashemi, S. M. B., Niakousari, M., Saharkhiz, M. J., \& Eskandari, M. H. (2012). Effect of Satureja khuzestanica essential oil on oxidative stability of sunflower oil during accelerated storage. Natural Product Research, 26(15), 1458-1463.

https://doi.org/10.1080/14786419.201 $\underline{1.606220}$

Kochhar, S., \& Rossell, J. (1990). Detection estimation and evaluation of antioxidants in food system. In Hudson, B.J.F (Ed) Food antioxidants. Barking, England: Elsevier Science publishers Ltd.

Liu, H., Xu, X., \& Guo, S. (2007). Rheological, texture and sensory properties of low-fat mayonnaise with different fat mimetics. LWT - Food Science and Technology, 40(6), 946-954. https://doi.org/10.1016/J.LWT.2006.1 $\underline{1.007}$

Mc.Clements, D. (1999). Food Emulsions Principles, Practice and Techniques. (C. Blvd \& N. W. B. Raton, Eds.). Florida: CRC Press LLC.

MCclements, D., \& Decker, E. (2000). Lipid oxidation in oil-in-water emulsions: impact of molecular environment on chemical reactions in heterogeneous food systems. Journal of Food Science, 65(8), 1270-1282. https://doi.org/10.1111/j.13652621.2000.tb10596.x 
Moslehishad, M., Ehsani, M. R., Salami, M., Mirdamadi, S., Ezzatpanah, H., Naslaji, A. N., \& Moosavi-Movahedi, A. A. (2013). The comparative assessment of ACE-inhibitory and antioxidant activities of peptide fractions obtained from fermented camel and bovine milk by Lactobacillus rhamnosus PTCC 1637. International Dairy Journal, 29(2), 82-87.

https://doi.org/10.1016/J.IDAIRYJ.20 $\underline{12.10 .015}$

Mun, S., Kim, Y.-L., Kang, C.-G., Park, K.-H., Shim, J.-Y., \& Kim, Y.-R. (2009). Development of reduced-fat mayonnaise using $4 \alpha$ GTase-modified rice starch and xanthan gum. International Journal of Biological Macromolecules, 44(5), 400-407. https://doi.org/10.1016/j.ijbiomac.200 $\underline{9.02 .008}$

Munizaga, T., \& Canovas, B. (2005). Rheology for the food industry. $J$. of Food Eng, 67, 147-156.

Nagwa, M., Rasmy, Amal, A., Hasan, I. Mervat, Foda, and M. Marwa. 2012, Assesment of the antioxidant activity of sage (Salvia officinalis) extracts on the shelf life of mayonnaise. World $J$. Dairy Food Sci., 7(1), 28 - 40.

Raymundoa, A., J.M. Franco, J. Empis, and I. Sousa. 2002. Optimization of the composition of low fat oil in water emulsions stabilized by white lupin protein. J. American. Oil. Chem. Soc. 79: 783-790.

Ricardo, M.A., J.M. Franco, and C. Gallegos. 2003. Influence of compositionof emulsifier blends on the rheological properties of salad dressing type emulsion. Food Sci and Technology, 9(1), 53-63
Shahidi, F., \& Wanasundara, U. (2002). Methods for measuring oxidative rancidity in fat and oil. (I. Marcel Dekker, Ed.) (2nd ed.). New York: Food Lipid - Chemistry, Nutrition and Biotechnology. 